\title{
Service Recovery-A Promising Strategy for Customer Loyalty
}

\author{
Dr. A. Kumudha ${ }^{1}$, Barkath Unissa .. ${ }^{2}$ \\ ${ }^{1}$ Associate Professor, PSGR Krishnammal College for women, Coimbatore, India \\ ${ }^{2}$ Research Scholar, Bharathiar University, Coimbatore, India
}

\begin{abstract}
Service recovery plays a crucial role in building loyalty of a customer. Even a brand loyal customer tends to become a brand switcher if his or her complaints are not dealt with effectively and efficiently. Customer's judge the service quality to a large extent based on the encounter one has to deal with during a service failure. An effective recovery process reassures not only loyalty of a customer but also through positive word of mouth gains new customers. Hence there is no denial of the fact that good service recovery is a powerful marketing tool of a service marketer. This paper examines how to build customer loyalty through service recovery in apparel retail sector.
\end{abstract}

Keywords: Apparel, Brand, Loyal, Recovery, Word of mouth

\section{Introduction}

A retail market today is flooded with variety of products and brands; a customer has wide choice of brands and products, hence the customer always looks for value in their purchases. It takes less than a minute for a customer to switch over to another brand, but a long time to gain one for a marketer; such is the competition in retail sector.Many a times it is not the outcome of a service recovery but the way in which the customer is treated during a service failure has a lasting impression in the minds of a customer. Hence a marketer has to be courteous and sincere during such encounters, and cautious when it comes to dealing with service failure and complaints, because you either gain a customer for life time or lose one forever.

\section{Importance of service Recovery}

Service recovery originates into picture when something in a service delivery goes wrong. The service recovery company ideally takes ensures that thecustomer gets their desired outcome anyway, and later rectifies their own process so that the failure doesn't reoccur. Service recovery has received attention for over 20 years within service management and service marketing. Since the cost of gaining a new customer usually greatly exceeds the cost of retaining a customer (it is often stated that it costs five times as much to attract a new customer as maintaining one), managers are increasingly concerned with minimizing customer defections.

When it comes to immediate recovery after a service breaks down, the company representatives need to consider why the service delivery broke down as the reason for the break down affects the recovery expected by the company. If the breakdown occurs due to mistakes or errors by the service personnel or external sources the recovery should be psychological then the employee needs to apologize for the inconvenience. If the error however is due to errors in the service architecture the recovery effort needs to be tangible and the customer should be compensated.
The principle behind this is that customers are more satisfied with their encounter if the first person they contact about a problem takes the initiative to fix things without having to send the request up the chain to their manager. It lets employees focus on solving problems.

Having dealt with the customer recovery, a company should ask itself how it might avoid the failure reoccurring. By analysing what happened and changing their routines the company can perform operations recovery. If the failure is bound to happen due to company procedures, the standard solution space for employees need to be defined. Another part of getting the organization prepared for future failures is to train their employees to provide great recovery in the future (employee recovery).Hence the present study is undertaken in order to understand the service recovery practices followed in apparel retail sector and its impact on customer loyalty.

\section{Objective of the Study}

1. To analyze the effectiveness of Service recovery and its impact on Customer loyalty.

2. To study the Customer's Value and satisfaction from the service offered.

\section{Research Methodology}

The study is confined only to top 10 apparel retail stores in Bangalore, and the customers who visit these stores. The sample size used for the study is 250 customers. The research instrument used for the study is a questionnaire. These customers were personally contacted by the researcher and the response was collected.Various tools used for the data analysis are Frequency table and Karl Pearson's correlation and mean and standard deviation.

\section{Analysis}

An attempt has been made to know about the relationship between service recovery and customer loyalty, for this purpose the after sales services are considered and this is 


\section{International Journal of Science and Research (IJSR) \\ ISSN (Online): 2319-7064 \\ Index Copernicus Value (2013): 6.14 | Impact Factor (2014): 5.611}

linked to the customer loyalty using Karl Pearson correlation, and the details are shown in the following table.

\section{Hypothesis:}

Higher (lower) theCustomer satisfaction about service recovery higher (lower) will be the customer Loyalty.

\section{Null Hypothesis:}

There is no significant difference between the service recovery and the customer loyalty.

\section{Alternative Hypothesis}

There is a significant difference between the service recovery and the customer loyalty. i.e. when the service recovery is higher (lower) then the Customer loyalty is higher (lower).

Table 1: Correlation Between Service Recovery and Customer Loyalty

\begin{tabular}{|c|c|c|}
\hline Factor & Service Recovery & Customer Loyalty \\
\hline Service & 1 & $.611^{* *}$ \\
\cline { 2 - 3 } Recovery & & 0 \\
\hline \multirow{2}{*}{$* *$. Correlation is significant at the 0.01 level (2-tailed). } \\
\hline
\end{tabular}

The Karl Pearson's correlation coefficient for these two variables is 0.611 which is positive and is significant at 0.01 level. Hence it is concluded that these two characteristics are significantly positively correlated. And therefore it rejects null hypothesis and accepts alternative hypothesis. This implies that if the recovery process of any complaint management is effective then the customer does not become a brand switcher in fact the customer stays loyal towards the retailer or brand.

\section{Findings}

The following are the findings that could be determined from the analysis

- 43.6 Percent of the customers agree that customers can contact the store easily while making a complaint

- 40.8 percent are neutral to the fact that complaints are taken seriously by the store.

- 42.4 Percent of the customers agree to the fact that after sales service of the store is good.

- 38 percent of the customers agree that complaints are dealt speedily and immediately.

- 52.4 percent of the customers agree that complaints are dealt by employees who understand the issue.

- 44.4 percent of the customers agree that they are treated fairly during a complaint.

- 40.4 percent of the customers agree that complaints are investigated fairly and thoroughly.

- 46 percent of the customers agree that they are told the truth and receive an apology if the organization is at fault.

- 34 percent of the customers agree that the store redresses the issue with fast resolutions.

- 64.4 percent of the customers agree to the fact that they would like to do business with the store again,

- 63.2 percent agree that their choice to purchase from the store is good,

- 60 percent agree that they would recommend the stores products to family and friends,
- 55.6 percent of the customers agree that they switch the brand of store very often,

- 51.6 percent agree that they say positive things about the store

- 56.4 percent of the customers encourage others to do business with the store.

It is inferred from the analysis that less than 50 percent of the customers agree to the fact that the after sales service is good, whereas the remaining 50 percent do not agree or neutral. It could be concluded that majority of the customers are not happy about the after sales service provided by the store with respect to complaint management, customers feedback says that the complaints were not handled to 100 percent satisfaction level. It is also inferred from the above analysis that only about 50 percent of the customers seem to be loyal whereas the remaining 50 percent are either neutral or disagree towards their loyalty to the store. Hence it is concluded that the store can provide better service to make the customer brand loyal.

\section{Suggestions}

1. It is very much essential for the store managers to hire good employees with the right attitude because customer's judge the service quality to a large extent based on the encounter one has to deal with during a service failure.

2. Employees can be constantly trained to handle service failures effectively.

3. Store can make things easier for customers during a service failure thereby the customers feel valued. Many a times it is not the outcome of a service recovery but the way in which the customer is treated during a service failure has a lasting impression in the minds of a customer.

4. Whenever there occurs a service failure, Employee can compensate the customerin order to turn the negative experience in to positive one. This will in turn result in improved loyalty and positive word of mouth advertisement.

\section{Conclusion}

In today's competitive economy, good service is nice but, it will not keep customers from looking at your competition. You need awesome, incredible and WOW service consistently. The growing middle class is an important factor contributing to the growth of retail in India. By 2030, it is estimated that 91 million households will be 'middle class', up from 21 million today. Also by 2030, 570 million people are expected to live in cities, nearly twice the population of the United States today.Thus, with tremendous potential and huge population, India is set for high growth in consumer expenditure. With India's large 'young' population and high domestic consumption, the macro trends for the sector look favourable. 


\section{References}

[1] Cook, S. (2012). Complaint handling and culture change. In Complaint Management Excellence (First ed., pp. 163-182). London: Kogan Page Limited.

[2] K.Gupta, S. (2010). Parametric Tests. In Business Research Methods (pp. 9.5-9.7). New Delhi: Kalyani.

[3] Mishra, A., \& Mishra, R. (2009). Customer complaints and customer service. In Customer Service in Retailing (First ed., pp. 256-263). New Delhi: Biztantra.

\section{Author Profile}

Ms. Barkath Unissa completed her M.B.A. from P.S.G.R.Krishnammal College for women, affiliated to Bharathiar University, Coimbatore; MPhil from Madurai kamaraj university, Madurai. She has 14 years' experience in academic. Her specialization is HRD \& Marketing. She has served as Assistant professor in institutions like Garden City College; CMR institute of management studies and Christ University, Bangalore. She has also published several articles and presented papers in national and international level conferences. Presently she is a research scholar pursuing her doctorate in the field of Management, Bharathiar University Coimbatore.

Dr. A. Kumudha completed her M.B.A. from the Regional Engineering College (NIT), Tiruchirapalli; M.Phil. \& B.L. from Bharathidasan University, Tiruchirapalli and Ph.D. from the Bharathiar University, Coimbatore. She has 28 years' experience in academic. Her specialization is HRD \& Marketing. She has served as Senior-cum-Research in Binary University College, Malaysia (2005-06) and Faculty member in Business Studies at Ibra College of Technology, Sultanate of Oman(2008-10). She has also published several articles and presented papers in national and international level conferences. Presently she is working as Associate Professor in the Department of Business Management at P.S.G.R.Krishnammal College for Women, affiliated to Bharathiar University, Coimbatore. 